\title{
Insights of microorganisms role in rice and rapeseed wastes as potential sorbents for metal removal
}

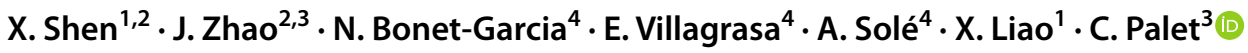

Received: 5 August 2021 / Revised: 20 January 2022 / Accepted: 25 January 2022 / Published online: 19 February 2022

(c) The Author(s) 2022

\begin{abstract}
Rice and rapeseed agricultural wastes, as nonliving biomass, are proposed for heavy metal remediation in polluted effluents (chromium, cadmium, copper and lead). The physicochemical characterization of these biomasses shows that the surface of both sorbents is negatively charged (zeta potential), the surface area of sorbents is 4.39 and 40.7 (Brunauer-EmmettTeller), and the main functional groups are carboxylic and hydroxyl (attenuated total reflection Fourier-transform infrared spectroscopy). The main purpose of this work is to evaluate the insights of microorganisms associated with these nonliving biomasses in the removal of heavy metals from synthetic aqueous solutions, adjusted at $\mathrm{pH} 4.0$ (as the best acidic condition for the sorption process). The isolates (Bacillus genus in rice and Escherichia, Micrococcus and Staphylococcus genus in rapeseed) remove heavy metals from mentioned solutions, mainly in consortia, with contribution percentage over than $80 \%$ of total metals. In addition, when they are present in biomass, they provide an additional metal removal effect, especially in rapeseed biomass system and with multiple heavy metals aqueous solutions: i.e. $\mathrm{Cr}(\mathrm{III})$ removal, at $4 \mathrm{mmol} / \mathrm{L}$, increases from 70 to $100 \%$. This knowledge makes possible the use of the nonliving biomasses with no need for any special pretreatment against the microorganisms, prior to their use as metal sorbents that implies their good feasibility for application from an economical point of view.
\end{abstract}

Keywords Biomass waste valorization $\cdot$ Sorption $\cdot$ Uptake heavy metals $\cdot$ Bacteria

\section{Introduction}

Editorial responsibility: Maryam Shabani.

$\mathrm{X}$. Shen and J. Zhao have contributed equally.

C. Palet

cristina.palet@uab.cat

1 Oil Crops Research Institute of Chinese Academy of Agricultural Sciences/Key Laboratory of Biology and Genetic Improvement of Oil Crops of the Ministry of Agriculture, Wuhan 430062, China

2 Key Laboratory of Optoelectronic Devices and Systems, College of Physics and Optoelectronic Engineering, Shenzhen University, Shenzhen 518060, China

3 GTS-UAB Research Group, Department of Chemistry, Facultat de Ciències, Universitat Autònoma de Barcelona, 08193 Cerdanyola del Vallès, Catalunya, Spain

4 Department of Genetics and Microbiology, Facultat de Ciències, Universitat Autònoma de Barcelona, Edifici C-Campus de La UAB, Bellaterra, 08193 Cerdanyola del Vallès, Catalunya, Spain
Heavy metal (HM) pollution has mainly become a serious threat to the environment due to anthropogenic activities (Bhattacharya et al. 2015). This increase in attention is due to the high toxicity, persistence in sediment and accumulation in biological tissues of HMs (Martín et al. 2015). HMs can be incorporated into the food chain, which can lead to gastrointestinal, neurological, haematic and renal diseases, among others (Kim and Kan 2016; Zhao et al. 2020). Consequently, the world is facing a critical water quality problem, which is threatening to animals and human beings (Azizullah et al. 2011). Relatively modest concentrations of $\mathrm{Cr}$ (III), $\mathrm{Cd}(\mathrm{II})$ and $\mathrm{Pb}$ (II) have toxic effects on the environment and humans. $\mathrm{Cu}$ (II) is also a potential toxicant at high doses (Tchounwou et al. 2012).

The main heavy metal pollutants and their main sources have included fertilizer leaching, sewage discharge, industrial wastewater and urban construction over the last decades (Nguyen et al. 2013; Addel-Ghani and El-Chaghaby 2014; Luo et al. 2017). In particular, the pollution of water 
resources by HMs is an alarming issue in China, where large amounts of HMs have been found in groundwater and drinking water (Dai et al. 2018).

Conventional physicochemical techniques for treating effluents laden with HMs include ion exchange, solvent extraction, electrochemical treatment and membrane filtration technologies (Yin et al. 2019). These methods are usually too expensive and not eco-friendly due to the liberation of toxic chemical sludge that can cause secondary pollution (Carolin et al. 2017; Kumar and Khan 2021). Therefore, using low-cost biosorption approaches for the removal of harmful heavy metals from water resources and wastewaters is one of the most important goals in environmental science (Zhao et al. 2019; Zhang et al. 2020; Zhao et al. 2020). One of the types of biosorption HM removal technologies, which consists of the use of nonliving biological materials, has recently emerged as a cost-effective, eco-friendly and simple alternative to remove toxic HMs from water or to render these pollutants harmless (Senthil Kumar and Gunasundari 2018; Calderón et al. 2020). Therefore, nonliving and metabolically inactive biomaterials from plants have been increasingly studied (Jain et al. 2015; Zhao et al. 2020). In particular, rice (Oryza sativa L., RO), which is the staple food for more than $50 \%$ of the world's population (Zhou et al. 2014), and rapeseed (Brassica napus L., LO), which is an oilseed crop and the second largest source of vegetable oil (FAO 2014), are both widely planted in Hunan Province, China. RO and LO have been widely studied in environmental fields, in which RO and LO crop varieties have been planted in contaminated soils for heavy metal uptake and soil remediation (Cárdenas-Aguiar et al. 2020; El-Hassanin et al. 2020). After harvesting, nonliving RO and LO residues (biomass), such as their husks (Zhan et al. 2020) and straw compost (Yu et al. 2020), have been studied as potential adsorbents for the removal of heavy metals from contaminated water. Otherwise, it is largely known that living organisms (bacteria and others) are generally exposed to mixtures of metals in the environment (Vijver et al. 2011; Mebane et al. 2020). Hence, bacteria show resistance mechanisms such as extracellular sequestration, intracellular sequestration, active export and enzymatic detoxification, which help them interact with metals and tolerate their toxicity and deleterious effects (Yin et al. 2019; Villagrasa et al. 2021).

Despite the extensive information mentioned above, nothing is known about the role of RO- and LO-associated microorganisms. Consequently, the aims of this work are (i) to quantify the HM sorption potential of nonliving RO and LO biomass in an HM-contaminated aqueous solution, (ii) to determine the identity of RO and LO biomass-associated microorganisms and (iii) to unravel their role in the HM sorption process. Thus, to discuss the role of isolated microorganisms in the HM sorption process, a multiple analytical approach was followed by using different techniques: (i) attenuated total reflection Fourier-transform infrared (ATRFTIR), zeta potential and Brunauer-Emmett-Teller (BET) techniques are employed to identify the properties of the assayed nonliving biomass (type of functional groups and electronic charge present on the surface of materials along with the area, volume and morphology of materials), and (ii) the adsorption capabilities of the nonliving assayed biomass are compared and studied with/without microorganisms via batch adsorption experiments. With this purpose, an economical and natural alternative/substitute for the decontamination of HM-containing effluents is developed by taking advantage of RO and LO straw residues. Moreover, to the best of our knowledge, this paper is the first to describe the role of microorganisms isolated from $\mathrm{LO}$ and $\mathrm{RO}$ wastes in regard to HM sorption capacity.

\section{Materials and methods}

\section{Materials and solutions}

Rice (Oryza sativa L., RO) and rapeseed (Brassica napus L., LO) were provided by the Oil Crops Research Institute of the Chinese Academy of Agriculture (Wuhan, China). Both biomasses were first immersed in a clean water solution, phases were separated by decantation, and then, biomasses were ground and dried for further use in corresponding metal sorption experiments. All chemicals were of analytical grade. Stock solutions (approximately $1000 \mathrm{mg} / \mathrm{L}$ ) were prepared by dissolving the required amounts of $\mathrm{Cr}\left(\mathrm{NO}_{3}\right)_{3} 9 \mathrm{H}_{2} \mathrm{O}$, $\mathrm{Cu}\left(\mathrm{NO}_{3}\right)_{2} 3 \mathrm{H}_{2} \mathrm{O}, \mathrm{Cd}\left(\mathrm{NO}_{3}\right)_{2} 4 \mathrm{H}_{2} \mathrm{O}$ and $\mathrm{Pb}\left(\mathrm{NO}_{3}\right)_{2}$ (all $99 \%$ from Panreac, Barcelona, Spain).

\section{Characterization}

\section{Physicochemical characterization}

$\mathrm{RO}$ and LO nonliving biomasses have been properly characterized. Therefore, the physicochemical properties of the biomass, including the $\mathrm{pH}$, mineral composition, surface area and surface charge, along with the identification of functional groups, can help to explain the process of metal sorption. Attenuated total reflection Fourier-transform infrared (ATR-FTIR, Tensor 27, Bruker, USA) spectroscopy was performed to identify the chemical functional groups present on the biomass wastes used as sorbents. The FTIR data were obtained from 600 to $4000 \mathrm{~cm}^{-1}$ with an average of 64 scans at a $4.0 \mathrm{~cm}^{-1}$ resolution; this characterization was performed at the Chemistry Analysis Service of our university ("Servei d'Anàlisi de Química") (https://sct.uab.cat/ saq/es) (UAB, Catalunya, Spain). The detailed procedures to determine the biomass $\mathrm{pH}$, mineral composition, surface 
area and surface charge are summarized in Supplementary Material (Text S1).

\section{Characterization of microorganisms}

Strain isolation Microbial strains were isolated from the $\mathrm{RO}$ and LO waste plants. For bacterial growth, $0.100 \mathrm{~g}$ of each plant was mixed with $10.0 \mathrm{~mL}$ of Luria-Bertani (LB) broth medium containing tryptone $(10.0 \mathrm{~g} / \mathrm{L})$, yeast extract $(5.00 \mathrm{~g} / \mathrm{L})$ and sodium chloride $(10.0 \mathrm{~g} / \mathrm{L})$ at $\mathrm{pH} 7.0$ and then placed in an orbital shaking incubator (Infors HT, Ecotron, Switzerland) at $150 \mathrm{rpm}$ and $27 \pm 1{ }^{\circ} \mathrm{C}$ for $24 \mathrm{~h}$. Subsequently, $100 \mu \mathrm{L}$ aliquots of each sample were spread onto LB agar plates consisting of LB broth medium along with bacteriological agar $(15.0 \mathrm{~g} / \mathrm{L})$ and incubated again for $24 \mathrm{~h}$ at $27 \pm 1{ }^{\circ} \mathrm{C}$.

To determine the number of colony forming units per volume (cfu/mL) in each original biomass (RO and $\mathrm{LO}$ ), $0.1 \mathrm{~mL}$ of the corresponding biomass/solution suspension, which was $0.1 \mathrm{~g}$ of biomass in $10 \mathrm{~mL}$ of sterile double deionized water, was spread in triplicate onto LB agar plates. Then, the samples were incubated at $27 \pm 1{ }^{\circ} \mathrm{C}$ for $24 \mathrm{~h}$.

Phenotypic characterization Phenotypic characterization of the different microorganisms associated with rice and rapeseed biomass samples was performed from single colonies collected from well-isolated cultures grown on LB plates. Morphological cell characteristics were examined with a conventional Olympus BH2 (Olympus, Japan) light microscope. Gram, Wirtz-Conklin spore and capsule staining were performed according to Doestch (1981), Schaeffer and Fulton (1933) and Anthony (1931), respectively. Oxidase activity was tested employing oxidase strips (Oxoid Ltd., Basingstoke, UK). Catalase enzymatic activity analysis was performed by applying a $3 \%(\mathrm{v} / \mathrm{v}) \mathrm{H}_{2} \mathrm{O}_{2}$ solution on each isolate to evaluate enzyme-generated oxygen bubble formation (Bergey and Holt 1994). Moreover, DNase activity and the degradation of Tween 80 were examined according to the methodology reported by Høvik Hansen and Sørheim (1991). The detection of phosphate-solubilizing microorganisms was performed following the protocol reported by Nath et al. (2017). Biochemical characterization was accomplished through BioMérieux ${ }^{\mathrm{TM}}$ Clinical Diagnostic Kits (BioMérieux ${ }^{\circledR} s a$, Marcy-l'Etoile, France).

Further characterization was developed by analysing microorganism growth in different selective solid and/or differential media after $24 \mathrm{~h}$ of incubation at $27^{\circ} \mathrm{C}$. These media included Vogel-Bonner E (VBE; Southern Group Laboratory, UK), minimal medium Vogel-Bonner (MMVB; Southern Group Laboratory, UK), mannitol salt and MacConkey (Scharlau, Spain). In addition, haemophilic activity was assessed through blood agar plates (Scharlau, Spain), and anaerobic growth was assayed on LB agar plates for
1 week at $27^{\circ} \mathrm{C}$ using an Anaerocult system (Merck KGaA, Darmstadt, Germany). Antibiotic resistance profiles were recovered by applying an antibiotic susceptibility test based on the Kirby-Bauer disc diffusion method (Sayah et al. 2005). Here, the tested antibiotics and their respective concentrations were as follows: ampicillin $-10 \mu \mathrm{g}$, tetracycline $-30 \mu \mathrm{g}$, and nalidixic acid-30 $\mu \mathrm{g}$.

Genotypic characterization For genotypic characterization, the total genomic DNA was extracted from each isolate using a bacterial genomic DNA isolation kit (Norgen Biotek Corp, Canada). The template DNA concentration was assessed by measuring the absorbance at $260 \mathrm{~nm}$ using an Ultrospec 1100 Pro UV/Vis spectrophotometer (Amersham Biosciences, USA). PCR cycling was executed with a Techne FTC 3G/02 thermal cycler (Techne, USA) and conducted for $5 \mathrm{~min}$ at $95^{\circ} \mathrm{C}$ for initial denaturing, followed by an amplification cycle, 23 cycles of $1 \mathrm{~min}$ at $95{ }^{\circ} \mathrm{C}, 1 \mathrm{~min}$ at $55^{\circ} \mathrm{C}, 2 \mathrm{~min}$ at $72{ }^{\circ} \mathrm{C}$ and a final extension of $10 \mathrm{~min}$ at $72{ }^{\circ} \mathrm{C}$. Amplicons were visualized by electrophoresis on a $1.2 \%$ agarose gel in $1 \times \mathrm{TAE}$ buffer (Figure $\mathrm{S} 1$ ) and further purified with Monarch ${ }^{\circledR}$ nucleic acid purification kits (New England BioLabs, USA). DNA sequencing was performed at the UAB Genomics and Bioinformatics Service ("Servei de Genòmica i Bioinformàtica") (http://sct.uab.cat/genom ica-bioinformatica) (UAB, Catalunya, Spain). Universal 16S rRNA forward 27F (AGAGTTTGGATCMTGGCTC AG) and reverse 1492R (GGTTACCTTGTTACGACTT) primers were used.

To analyse the sequences of partial gene amplicons of $16 \mathrm{~S}$ $r$ RNA and to exclude ambiguous data, SEQUENCHER software version 5.4.6 (http://www.genecodes.com/) was used. The obtained sequences were then compared to those existing in the NCBI database and matched with accessible references (www.ncbi.nlm.nih.gov) through the Ribosomal Database Project at Michigan State University (RDP-II) (http:// rdp.cme.msu.edu/) and BLAST software (https://blast.ncbi. nlm.nih.gov/Blast.cgi) (Cole et al. 2014). Finally, they were deposited in the GenBank sequence database.

\section{Experimental procedures}

\section{Batch sorption experiments}

Sorption experiments were carried out at room temperature $\left(25 \pm 1{ }^{\circ} \mathrm{C}\right)$. A multimetal solution composed of $0.18 \mathrm{mmol} / \mathrm{L}$ solutions of $\mathrm{Cr}(\mathrm{III}), \mathrm{Cd}(\mathrm{II}), \mathrm{Cu}$ (II) and $\mathrm{Pb}$ (II) was prepared. When conducting the isotherm sorption experiments for single-metal systems, the initial heavy metal concentrations ranged from 0.05 to $6 \mathrm{mmol} / \mathrm{L}$.

Batch sorption experiments were performed with the following steps: $25 \mathrm{mg}$ of each sorbent was placed in $5 \mathrm{~mL}$ Falcon tubes, and then, $2.5 \mathrm{~mL}$ of a heavy metal aqueous 
solution was added into the tube. Later, samples were placed in a rotary mixer (CE 2000 ABT-4, SBS Instruments SA, Barcelona, Spain) and shaken at $25 \mathrm{rpm}$ for $24 \mathrm{~h}$. The two phases were separated by decantation, and later, the aqueous phase was filtered through $0.22 \mu \mathrm{m}$ Millipore filters (MillexGS, Millipore). Finally, inductively coupled plasma-mass spectrometry (ICP-MS, XSERIES 2 ICP-MS, Thermo Scientific, USA) was used to analyse the final concentration of heavy metals in the supernatant phase.

The sorption/adsorption of the selected heavy metals by the sorbents was expressed as the sorption percentage, which was calculated according to Eq. (1). Furthermore, the capacity of the sorbent was calculated with Eq. (2) (Zhao et al. 2019):

$\%$ Sorption/Adsorption $=\frac{\left(C_{0}-C_{e}\right)}{C_{0}} \times 100$

$q_{e}=\frac{\left(C_{0}-C_{e}\right) \times V}{m}$

where $q_{e}(\mathrm{mmol} / \mathrm{g})$ is the sorption capacity of heavy metals, $V(\mathrm{~L})$ is the volume of the heavy metal solution, $C_{0}$ and $C_{e}$ are the initial and equilibrium heavy metal concentrations in solution (both in $\mathrm{mg} / \mathrm{L}$ ), respectively, and $m(\mathrm{~g})$ is the dry weight of the sorbent. All the results are expressed as the mean value of minimum duplicate measurements, and the standard deviation (SD) was used to analyse data errors.

Sorption experiments were carried out to optimize the working conditions, including the influence of $\mathrm{pH}$, initial metal concentration and contact time. Furthermore, kinetics and isotherm models were chosen to study the sorption process. The pseudo-first-order (PFO), pseudo-second-order (PSO) and Elovich models (Wang et al. 2015) are typically used to describe sorption processes, while the Langmuir and Freundlich isotherm models are typically used to describe the sorption mechanism for the interaction of heavy metal ions on a sorbent surface. The above-mentioned information details can be found in Supplementary Material (Text S2).

Additionally, experiments with sterilized biomasses were performed as described above. A complete autoclave cycle (Raypa, Terrassa, Spain) was performed for 1 to $1.5 \mathrm{~h}$ at $121{ }^{\circ} \mathrm{C}$ to eliminate live microorganisms, thereby allowing the uptake potential of sterile biomass to be tested. Therefore, sorption experiments were prepared with common biomasses and sterile biomasses, and the roles of the biomassassociated microorganisms in the metal uptake process were evaluated.

\section{Exposure of isolated strains to a heavy metal solution}

For each individual microbial strain, an aliquot of 2.00 of each strain culture $\left(\mathrm{OD}_{600}=1.2-1.4\right)$ grown on LB liquid
Table 1 Comparison of the adsorption capacity of metal ions from multiple metal systems (initial concentration of $0.18 \mathrm{mmol} / \mathrm{L}$ of $\mathrm{Cr}(\mathrm{III}), \mathrm{Cu}(\mathrm{II}), \mathrm{Cd}(\mathrm{II})$ and $\mathrm{Pb}(\mathrm{II})$ ) by different adsorbents under the same experimental conditions $\left(T=25 \pm 1^{\circ} \mathrm{C}, 25 \mathrm{mg}\right.$ of adsorbent, $2.5 \mathrm{~mL}$ of solution and a contact time of $24 \mathrm{~h}$ )

\begin{tabular}{lllll}
\hline Adsorbents & $\begin{array}{l}\mathrm{Cr}(\mathrm{III}) \\
q \times 10^{3} \\
(\mathrm{mmol} / \mathrm{g})\end{array}$ & $\begin{array}{l}\mathrm{Cu}(\mathrm{II}) \\
(\mathrm{mmol} / \mathrm{g})\end{array}$ & $\begin{array}{l}\mathrm{Cd}(\mathrm{II}) \\
(\mathrm{mmol} / \mathrm{g})\end{array}$ & $\begin{array}{l}\mathrm{Pb}(\mathrm{II}) \\
(\mathrm{mmol} / \mathrm{g})\end{array}$ \\
\hline Rice & $9.81 \pm 0.01$ & $9.75 \pm 0.01$ & $10.5 \pm 0.1$ & $8.92 \pm 0.01$ \\
Rapeseed & $7.24 \pm 0.01$ & $3.78 \pm 0.01$ & $6.76 \pm 0.01$ & $8.92 \pm 0.01$ \\
Pine & $7.35 \pm 0.01$ & $4.02 \pm 0.01$ & $1.48 \pm 0.01$ & $9.09 \pm 0.01$ \\
Poplar & $9.41 \pm 0.01$ & $7.04 \pm 0.01$ & $1.93 \pm 0.01$ & $7.04 \pm 0.01$ \\
Corn & $11.8 \pm 0.1$ & $10.1 \pm 0.1$ & $4.87 \pm 0.01$ & $1.78 \pm 0.01$ \\
Coffee shell & $2.48 \pm 0.01$ & $4.61 \pm 0.01$ & $0.75 \pm 0.01$ & $20.1 \pm 0.1$ \\
Sugar cane & $2.46 \pm 0.01$ & $3.41 \pm 0.01$ & $0.52 \pm 0.01$ & $9.59 \pm 0.01$ \\
Cork & $7.98 \pm 0.01$ & $5.92 \pm 0.01$ & $2.53 \pm 0.01$ & $11.5 \pm 0.1$ \\
Coffee grounds & $3.48 \pm 0.01$ & $7.10 \pm 0.01$ & $0.14 \pm 0.01$ & $10.8 \pm 0.1$ \\
\hline
\end{tabular}

medium for $24 \mathrm{~h}$ at $27^{\circ} \mathrm{C}$ was inoculated into $18.0 \mathrm{~mL}$ of $\mathrm{LB}$ broth medium containing $0.18 \mathrm{mM}$ of a heavy metal mixture (Cr(III), $\mathrm{Cd}(\mathrm{II}), \mathrm{Cu}(\mathrm{II})$ and $\mathrm{Pb}(\mathrm{II})$ ). For consortia, aliquots of $0.5 \mathrm{~mL}$ of individual strain were inoculated according to their isolation source into $18.0(\mathrm{RO})$ or $18.5(\mathrm{LO}) \mathrm{mL}$ of the above-mentioned LB mixed metal solution. Therefore, two microbial consortia (corresponding to each biomass) were formulated by mixing equal proportions of the pure cultures. Then, the cultures were placed in an orbital shaking incubator $(150 \mathrm{rpm})$ for $24 \mathrm{~h}$ at $27^{\circ} \mathrm{C}$.

After $24 \mathrm{~h}$, the samples were centrifuged (Centrifuge 5430, Eppendorf, Germany) at $8000 \mathrm{rpm}$ for $15 \mathrm{~min}$. Finally, the solution was analysed by using ICP-MS (XSERIES 2 ICP-MS, Thermo Scientific, USA) to analyse the concentrations of heavy metals in the supernatant phase.

\section{Results and discussion}

Taking into account previous research with other biomass materials (Dai et al. 2018), different agricultural wastes are compared in Table 1 in terms of their sorption capacities for the removal of HMs from multiple metal aqueous solutions containing $\mathrm{Cr}(\mathrm{III}), \mathrm{Cu}(\mathrm{II}), \mathrm{Cd}$ and $\mathrm{Pb}(\mathrm{II})$. Pine, poplar, coffee shell, sugar cane and coffee grounds all show high sorption capacities for $\mathrm{Cr}$ (III), $\mathrm{Cu}$ (II) and $\mathrm{Pb}$ (II) and low sorption capacities for $\mathrm{Cd}(\mathrm{II})$, as seen from the collected results (Table 1). In the case of corn wastes, it shows high sorption capacities for $\mathrm{Cr}$ (III), $\mathrm{Cu}$ (II) and $\mathrm{Cd}(\mathrm{II})$ and low sorption capacities for $\mathrm{Pb}$ (II). It is worth noting that the prepared RO and LO samples show good sorption capacities for all metal ions compared with the other sorbents listed here. In particular, the case of $\mathrm{Cd}(\mathrm{II})$ is highlighted because both 
Table 2 Total concentrations of the minerals and heavy metals $(\mathrm{mg} / \mathrm{Kg})$ along with the zeta potential and BET results of rice (RO) and rapeseed (LO) biomass

\begin{tabular}{|c|c|c|c|c|c|c|c|c|c|c|c|}
\hline & $\mathrm{Fe}$ & $\mathrm{Mn}$ & $\mathrm{Ni}$ & $\mathrm{Cu}$ & As & $\mathrm{Pb}$ & $\mathrm{Mg}$ & $P$ & $K$ & ZETA & BET \\
\hline RO & 6,291 & 2,348 & 70.5 & 747 & 15.2 & 1,691 & 2,051 & 25,108 & 28,700 & -12.4 & 4.39 \\
\hline LO & 6,410 & 208.1 & 40.5 & 229 & 15.5 & 568.7 & 554.0 & 24,280 & 37,900 & -1.44 & 40.7 \\
\hline
\end{tabular}

sorbents (RO and LO) show higher affinity for Cd than the majority of other biomass materials.

In this work, the authors wanted to distinguish between the nonliving biomass and the living microorganism systems that are present in them.

\section{Nonliving biomass characterization}

The concentrations of some minerals $(\mathrm{P}, \mathrm{K}$ and $\mathrm{Mg}$ ) and major metals ( $\mathrm{Fe}$ and $\mathrm{Mn}$ ) in the rice ( $\mathrm{RO}$ ) and rapeseed (LO) biomass materials are listed in Table 2. RO and LO have similar concentrations of some minerals. However, they differ in the contents of some others, such as $\mathrm{Mn}$ and $\mathrm{Mg}$, with RO having higher concentrations of these metal ions than LO; thus, RO has different physicochemical properties (Wang et al. 2015; Zhao and Zhou 2019). These differences have not been related to differences in the corresponding treatment of crops but can have an understandable role in the sorption process of each biomass waste system.

Table 2 also shows the zeta potential and BET values of RO and LO. Both biomass materials show negative zeta potential values, so a negative charge on their surface probably facilitates the sorption of cation metal ions via electrostatic attraction (Plank and Christian 2007). In addition, the difference in surface area of sorbents obtained from BET results gives enhanced surface area and a higher number of possible sorption sites for heavy metals (Sčíban et al. 2007) for LO in comparison with RO.

ATR-FTIR analysis was carried out to identify the functional groups present in the $\mathrm{RO}$ and $\mathrm{LO}$ biomass wastes that might be involved in the biosorption process. In Fig. 1, the FTIR spectra display several absorption peaks, indicating the complex nature of the examined biomaterials. As mentioned previously, cellulose, hemicellulose and lignin are the main components of agricultural straw biomass (Ghaffar and Fan 2014), and their functional groups (such as carboxylic and hydroxyl groups) can be found in the present biomasses (RO and LO) used as sorbents, which may participate in the proposed metal sorption processes (Zhao et al. 2020).

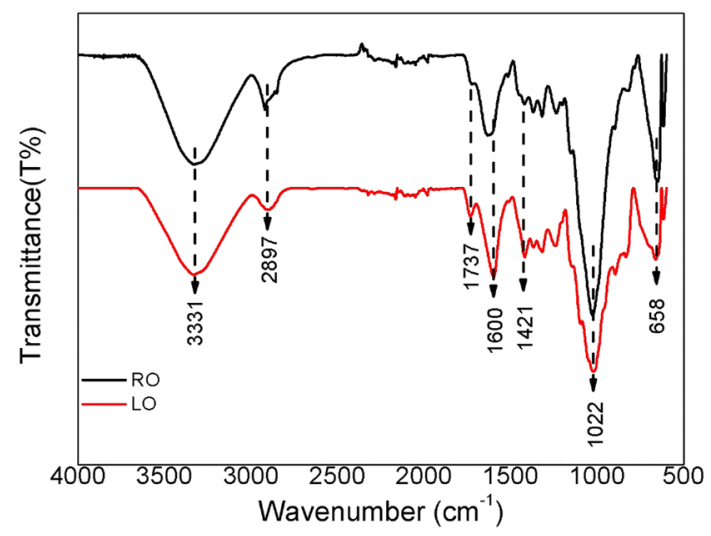

Fig. 1 ATR-FTIR spectra of RO and LO

\section{Microorganism identification}

\section{Phenotypic and genotypic characterization}

Through phenotypic analysis, a total of 8 microorganisms associated with the rice (R01, R02, R03 and R04) and rapeseed (L01, L02, L03 and L04) biomass samples were differentiated. A summary of the isolated strain characterization is shown in Table 3. After the colonies were grown on LB agar plates for $24 \mathrm{~h}$ at $27^{\circ} \mathrm{C}$, a preliminary phenotypic characterization of strains was performed, including macroscopic trait observations and cellular examination with optical microscopy. On the one hand, R01, R02, R02 and R04 present a similar macroscopic appearance, forming smooth, circular, nonpigmented and very mucoid colonies. On the other hand, L01 and L02 formed dry, nonpigmented, opaque and mucoid colonies, while L03 formed small, raised and white-coloured colonies, and L04 formed circular and convex colonies showing a bright yellowish pigment. Regarding microscopic cellular features, R01, R02, R03 and R04 are short, rod-shaped and gram-positive; additionally, all of them, except R03, produce spores. In contrast, L01 and L02 are rod-shaped, gram-negative and non-spore-forming bacteria. L03 and L04 are gram-positive and non-spore-forming cocci. In the first strain, cells are organized in grape-like clusters, while they are arranged in tetrads in the second strain. They all showed different patterns of motility and capsule formation. To further characterize the isolated strains, a physiologic and metabolic analysis was developed. 
Table 3 Phenotypic and genotypic characterization of the microorganisms isolated from the rice and rapeseed biomass wastes

\begin{tabular}{|c|c|c|c|c|c|c|c|}
\hline \multicolumn{5}{|c|}{ Phenotypic characterization } & & & \\
\hline \multirow{2}{*}{$\begin{array}{l}\text { Characters } \\
\text { Cell morphol- } \\
\text { ogy }\end{array}$} & \multicolumn{4}{|l|}{ RICE } & \multicolumn{3}{|l|}{ CANOLA } \\
\hline & Rod-shaped & Rod-shaped & Rod-shaped & Rod-shaped & Rod-shaped & $\begin{array}{l}\text { Cocci in grape- } \\
\text { like clusters }\end{array}$ & $\begin{array}{l}\text { Cocci arranged in } \\
\text { tetrads }\end{array}$ \\
\hline Gram stain & + & + & + & + & - & + & + \\
\hline Spore formation & + & + & - & + & - & - & - \\
\hline Motility & + & - & - & + & + & - & - \\
\hline $\begin{array}{l}\text { Capsule forma- } \\
\text { tion }\end{array}$ & - & - & - & + & + & - & - \\
\hline \multicolumn{8}{|l|}{ Enzymatic activity } \\
\hline Catalase & + & + & + & + & + & + & + \\
\hline Oxidase & + & + & - & - & - & - & + \\
\hline $\mathrm{H}_{2} \mathrm{~S}$ production & - & - & - & - & - & - & - \\
\hline Urease & - & - & - & - & - & - & - \\
\hline $\begin{array}{l}\text { Indole produc- } \\
\text { tion }\end{array}$ & - & - & - & - & + & - & - \\
\hline DNase & + & - & + & + & - & + & + \\
\hline Tween-80 & + & - & - & + & + & - & - \\
\hline $\begin{array}{l}\text { Phosphate } \\
\text { solubilization } \\
(\mathrm{mm})\end{array}$ & 10 & 8 & 5 & 3 & 8 & - & - \\
\hline \multicolumn{8}{|c|}{ Antibiotic resistance } \\
\hline Ampicilin & $\mathrm{S}$ & $\mathrm{R}$ & $\mathrm{R}$ & $\mathrm{R}$ & $\mathrm{R}$ & $\mathrm{S}$ & $\mathrm{R}$ \\
\hline Tetracycline & $\mathrm{R}$ & $\mathrm{R}$ & $\mathrm{R}$ & $S$ & $\mathrm{R}$ & $\mathrm{R}$ & $\mathrm{R}$ \\
\hline Nalidixic Acid & $\mathrm{R}$ & $\mathrm{R}$ & $\mathrm{R}$ & $\mathrm{R}$ & $\mathrm{R}$ & $\mathrm{R}$ & $\mathrm{R}$ \\
\hline \multicolumn{8}{|c|}{ Genotypic characterization } \\
\hline Strain & $\begin{array}{l}\text { Bacillus sp. } \\
\quad \text { R01 }\end{array}$ & $\begin{array}{l}\text { Bacillus sp. } \\
\quad \text { R02 }\end{array}$ & $\begin{array}{l}\text { Bacillus sp. } \\
\quad \text { R03 }\end{array}$ & $\begin{array}{l}\text { Bacillus sp. } \\
\quad \text { R04 }\end{array}$ & $\begin{array}{l}\text { Escherichia coli } \\
\text { L01 } \\
\text { Escherichia coli } \\
\text { L02 }\end{array}$ & $\begin{array}{l}\text { Staphylococcus } \\
\text { sp. L03 }\end{array}$ & $\begin{array}{l}\text { Micrococcus sp. } \\
\text { L04 }\end{array}$ \\
\hline $\begin{array}{l}\text { Accession } \\
\text { number }\end{array}$ & MK94285 & MK934695 & MK934698 & MK937732 & $\begin{array}{l}\text { MK940239 } \\
\text { MK937745 }\end{array}$ & MK942713 & MK942714 \\
\hline
\end{tabular}

All strains were positive for catalase, while only R01, R02 and L04 were positive for oxidase. R01, R02, R03, R04, L01 and L02 produce $\beta$-haemolysis, whereas L03 and L04 induce an a-haemolytic response. All isolates exhibited no $\mathrm{H}_{2} \mathrm{~S}$ production and were urease negative, and only L01 and L02 were positive for indole production. Moreover, all of them reveal distinct responses to DNA and Tween 80 (a nonionic surfactant) hydrolysis (Table 3). R01, R02, R03 and R04 are facultative anaerobes that develop a chemoorganoheterotrophic metabolism, and L01, L02, L03 and L04 are strictly aerobic bacteria. Regarding their growth on minimal, selective and differential media, R01, R02, R03 and R04 were able to grow on mannitol salt agar and MMVB medium but not on MacConkey agar or VBE medium. In the case of rapeseed-isolated microorganisms, L01 and L02 grew on MacConkey agar and MMVB, while L03 and L04 grew only on mannitol salt. The antibiogram results indicate that they are all resistant to nalidixic acid, but they show different susceptibility patterns in regard to tetracycline and ampicillin (Table 3). Last, rod-shaped strains from both the rice and rapeseed biomasses present the ability to solubilize inorganic phosphorus from insoluble compounds. This capacity, which is not detected with rapeseed coccoid strains, is considered one of the most relevant traits associated with plant phosphate nutrition by rhizosphere microorganisms (Alori et al. 2017).

For genotypic characterization, the DNA band of each strain obtained from PCR cycling was visualized in a 1.2\% agarose gel before being further purified and sequenced (Supplementary Material, Figure S1). The processed sequence was then entered into the Ribosomal Database Project website at Michigan State University (RDP-II) (https:// rdp.cme.msu.edu/classifier/classifier.jsp). The sequence analysis of the isolated strains shows their genus with a $100 \%$ probability. The sequence was then introduced in BLAST (Basic Local Alignment Search Tool) (https://blast. 
Fig. 2 Influence of the aqueous initial solution $\mathrm{pH}$ on the $\mathbf{a} \mathrm{RO}$ and $\mathbf{b}$ LO sorption systems. Experimental conditions: $T=25 \pm 1^{\circ} \mathrm{C}, 25 \mathrm{mg}$ of sorbent, $2.5 \mathrm{~mL}$ of aqueous solution with $0.18 \mathrm{mmol} / \mathrm{L}$ of each element and a contact time of $24 \mathrm{~h}$. The lines are a guide for the eyes
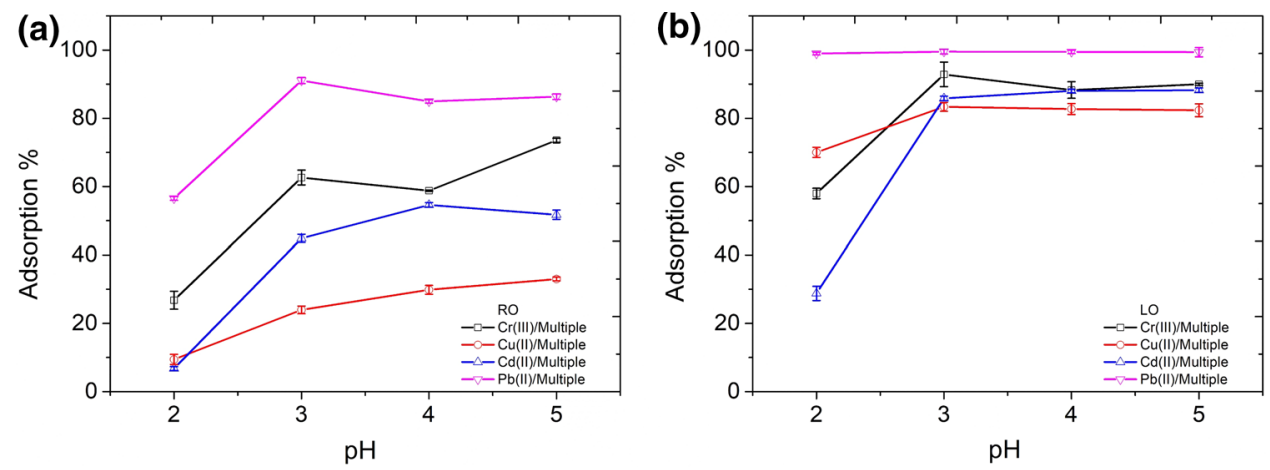

ncbi.nlm.nih.gov/Blast.cgi), displaying the following high degrees of gene sequence similarity: R01 Bacillus thuringiensis (99.6\%); R02 Bacillus subtilis (98.99\%); R03 Bacillus pumilus (99.3\%); R04 Bacillus cereus (99.8\%); L01 and L02 Escherichia coli (99.71\%); L03 Staphylococcus epidermidis (99.79\%); and L04 Micrococcus luteus (99.42\%). According to these results, the isolates were identified only at the genus level since further gene sequences are needed to certainly state that they belong to the specified species. At this point, the rapeseed-associated strain L01 was no longer considered for future experiments, as it was estimated to be the same as strain L02.

In general, terms, these findings are understandable, taking into account the origin of the samples, since the species of Bacillus and Micrococcus genera are widely distributed in the environment (Maldonado et al. 2010; Hashem et al. 2019). Moreover, isolated Bacillus strains have high phosphate solubilization potential, especially R01 and R02, which is related to their rhizosphere (roots) provenance and their ability to improve plant nutrient uptake. On the other hand, Micrococcus has been extensively shown to be both phyllospheric and rhizospheric genera that promote plant growth activities, specifically with rapeseed plants (Ghavami et al. 2017). The presence of E. coli suggests a faecal origin and can be explained by possible contamination during sample transport and handling and/or the erratic distribution of microorganisms in irrigation water (Luyt et al. 2012). In this way, the presence of Staphylococcus is presumably due to anthropogenic activities, since it is part of the human skin microbiome (Wood and Kelly 2010).

\section{Optimization of sorption conditions}

\section{Influence of the solution $\mathrm{pH}$}

To check the influence of the $\mathrm{pH}$ of the aqueous metal solution, the initial $\mathrm{pH}$ was adjusted to 2, 3, 4, 5 and 6 with either $\mathrm{HCl}$ or $\mathrm{NaOH}$. The following detailed experimental procedure is included in Text S2 (Supplementary Material).
As shown in Fig. 2, LO has a better sorption capacity than $\mathrm{RO}$, especially at $\mathrm{pH} \geq 3.0$. As expected, the metal sorption percentage for both biomaterials increased with increasing $\mathrm{pH}$. At $\mathrm{pH}$ 2.0, the lowest sorption percentages were found, probably because hydronium ions $\left(\mathrm{H}_{3} \mathrm{O}^{+}\right)$on the surface functional groups usually limit cation sorption due to their repulsive force (Feizi and Jalali 2015). Competitive sorption of heavy metal cations is also found for both biomaterials, as shown in Fig. 2. The sorption sequence of heavy metals by $\mathrm{RO}$ was ranked as $\mathrm{Pb}(\mathrm{II})>\mathrm{Cr}$ (III) $>\mathrm{Cd}(\mathrm{II})>\mathrm{Cu}$ (II) in all pH ranges, as shown in Fig. 2a. LO has a similar sorption trend. The higher adsorption percentage values found with LO for all heavy metal cations can be related to its enhanced surface area compared with RO (see Table 2), which leads to possibly higher sorption sites available, as mentioned previously. Considering that an aqueous solution $\mathrm{pH}$ above 5.0 can cause heavy metal precipitation (Shen et al. 2017), $\mathrm{pH}$ 4.0 was chosen in the following studies.

\section{Kinetics modelling}

The kinetics models used here to describe the sorption process include the PFO, PSO and Elovich models, which can be described in Text S2 (Supplementary Material). The experimental kinetic data for RO and LO from Figure $\mathrm{S} 2$, following the corresponding procedure described in Text S2, are adjusted to the models, as shown in Figure $\mathrm{S} 3$. The RO and LO constant values from the kinetic models, such as $k_{i}, q_{i}, \alpha$ and the calculated $q_{e}$ (experimental sorption capacity), are listed in Table 4 , together with the $\mathrm{R}^{2}$ values of each model.

The results of RO and LO indicate that the PFO, PSO and Elovich equations all fit well with the experimental data for all metal ions with high correlation coefficients $\left(R^{2}>0.960\right)$. In summary, the obtained results and model adjustments can explain why the biosorption processes of $\mathrm{RO}$ and LO are rate-controlled mainly by physisorption, and they can also follow a multilayer biosorption process, which is probably related to the aromatic structure of lignin, which 
Table 4 Biosorption kinetic constant values for $\mathrm{Cr}(\mathrm{III}), \mathrm{Cu}(\mathrm{II}), \mathrm{Cd}(\mathrm{II})$ and $\mathrm{Pb}(\mathrm{II})$ by $\mathrm{RO}$ and $\mathrm{LO}$ for each model

\begin{tabular}{|c|c|c|c|c|c|c|c|c|c|c|}
\hline & \multirow{2}{*}{$\begin{array}{l}\text { Experimental } \\
q_{\mathrm{exp}} \times 10^{3} \\
(\mathrm{mmol} / \mathrm{g})\end{array}$} & \multicolumn{3}{|l|}{$\mathrm{PFO}$} & \multicolumn{3}{|l|}{ PSO } & \multicolumn{3}{|l|}{ Elovich } \\
\hline & & $\begin{array}{l}k_{1} \\
\left(\min ^{-1}\right)\end{array}$ & $\begin{array}{l}q_{1} \times 10^{3} \\
(\mathrm{mmol} / \mathrm{g})\end{array}$ & $R^{2}$ & $\begin{array}{l}k_{2} \\
\left(\mathrm{~g} / \mathrm{mmol}^{*} \mathrm{~min}\right)\end{array}$ & $\begin{array}{l}q_{2} \times 10^{3} \\
(\mathrm{mmol} / \mathrm{g})\end{array}$ & $R^{2}$ & $A$ & $B$ & $R^{2}$ \\
\hline \multicolumn{11}{|c|}{$\mathrm{Cr}(\mathrm{III})$} \\
\hline RO & 8.70 & 160 & 8.10 & 0.972 & 67.6 & 3.80 & 0.972 & 6,063 & $2.8 * 10^{3}$ & 0.965 \\
\hline LO & 9.90 & 0.624 & 9.70 & 0.995 & 322 & 9.80 & 0.997 & 7,152 & $3.1 * 10^{24}$ & 0.998 \\
\hline \multicolumn{11}{|c|}{$\mathrm{Cu}(\mathrm{II})$} \\
\hline RO & 3.80 & 0.107 & 3.70 & 0.961 & 67.6 & 3.80 & 0.971 & 6,063 & $2.8 * 10^{3}$ & 0.968 \\
\hline LO & 9.90 & 0.662 & 9.70 & 0.997 & 418 & 9.80 & 0.998 & 11,970 & $7.0 * 10^{44}$ & 0.998 \\
\hline \multicolumn{11}{|c|}{$\mathrm{Cd}(\mathrm{II})$} \\
\hline RO & 6.70 & 0.194 & 6.60 & 0.997 & 168 & 6.60 & 0.997 & 12,110 & $1.2 * 10^{28}$ & 0.997 \\
\hline LO & 9.70 & 0.543 & 9.40 & 0.986 & 206 & 9.60 & 0.991 & 6,306 & $1.4^{*} 10^{20}$ & 0.992 \\
\hline \multicolumn{11}{|c|}{$\mathrm{Pb}(\mathrm{II})$} \\
\hline RO & 8.90 & 0.153 & 8.60 & 0.996 & 60.2 & 8.80 & 0.999 & 4,870 & $1.1 * 10^{12}$ & 0.998 \\
\hline LO & 14.0 & 0.845 & 14.0 & 0.999 & 746 & 14.0 & 0.999 & 8,526 & $5.6^{*} 10^{44}$ & 0.999 \\
\hline
\end{tabular}

Fig. 3 Freundlich and Langmuir biosorption isotherms of heavy metals in individual-element systems by $\mathbf{a}, \mathbf{b}$ RO and $\mathbf{c}, \mathbf{d}$ LO. Biosorption conditions: $T=25 \pm 1{ }^{\circ} \mathrm{C}, \mathrm{pH} 4.0,25 \mathrm{mg}$ of sorbent, $2.5 \mathrm{~mL}$ of aqueous solution and a contact time of $24 \mathrm{~h}$. The lines are a guide for the eyes
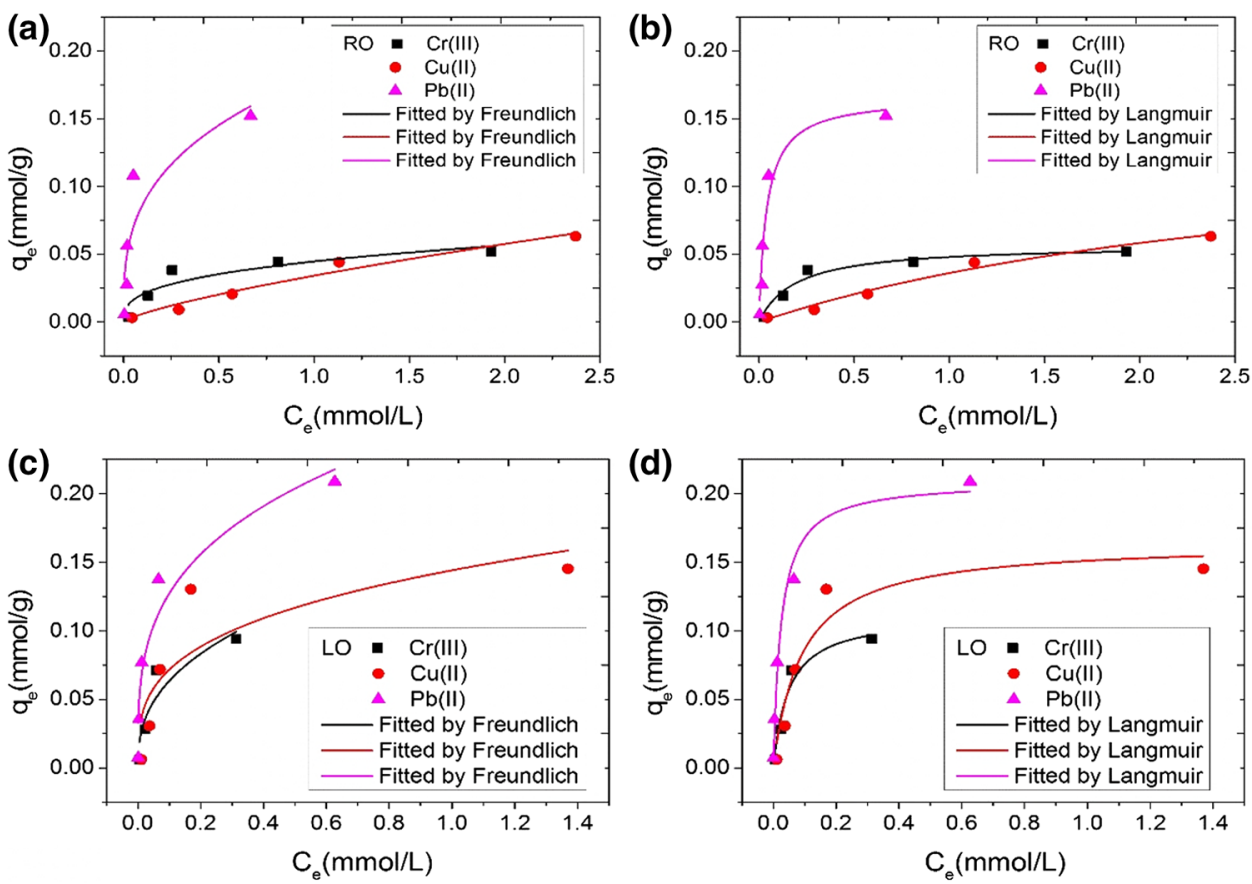

is predominant in the composition of both rice and rapeseed biomass wastes (Sharma et al. 2004; Hubbe 2021).

\section{Isotherm modelling}

To evaluate the maximum biosorption capacity of RO and LO, Langmuir and Freundlich isotherm models were used. Data results from the experiments of the initial metal concentration variation (Figure S4) are used in this case (following the corresponding procedure described in Text S2). The Langmuir model assumes that the uptake of metal ions occurs on a homogeneous surface, whereas the Freundlich model assumes it occurs on a heterogeneous surface, which can be described in Text S2 (in supplementary material).

The plots of $q_{e}$ (sorption capacity) versus $C_{e}$ (concentration at the equilibrium state) of each metal in a system with a single heavy metal are shown in Fig. 3. The corresponding constant values are shown in Table $\mathrm{S} 1$, including the $\mathrm{R}^{2}$ values for each model (see Text S2 for further Langmuir constant explanation).

In the present study, the Langmuir equation fits the experimental data better than the Freundlich equation in a system with a single heavy metal content (either by RO or LO). The Freundlich model cannot properly fit all the experimental 
Fig. 4 Comparison of the sorption capacities of nonsterile and sterile rice (RO) at different concentration levels of multimetal aqueous solutions. Experimental conditions: $T=25 \pm 1{ }^{\circ} \mathrm{C}, \mathrm{pH} 4.0,25 \mathrm{mg}$ of sorbent, $2.5 \mathrm{~mL}$ of metal solution and a contact time of $24 \mathrm{~h}$
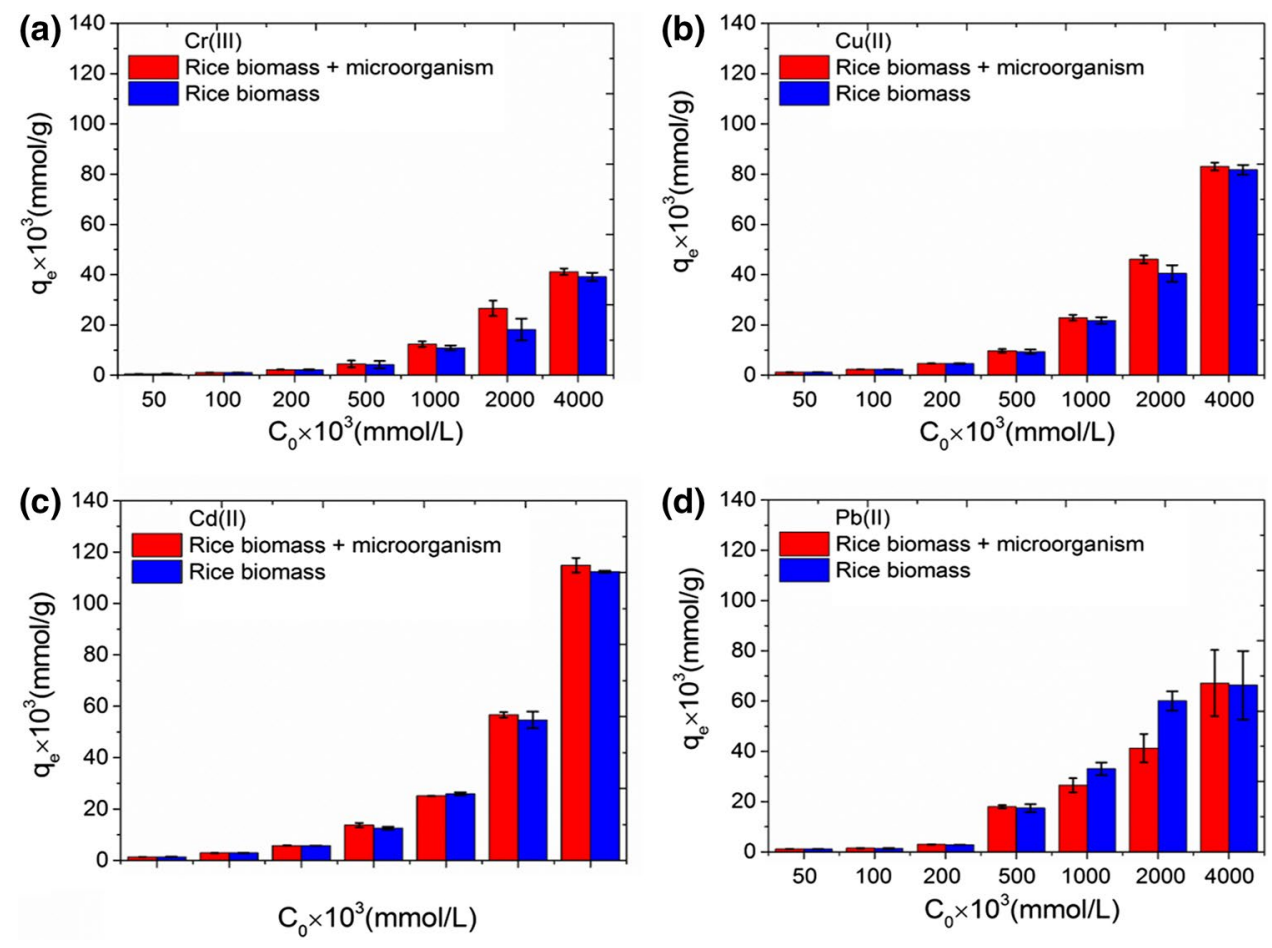

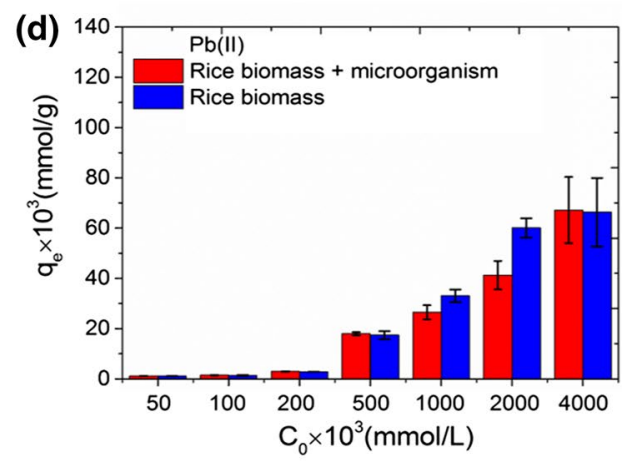

data, as the $\mathrm{R}^{2}$ values are generally lower than the $R^{2}$ values with the Langmuir model (shown in Table $\mathrm{S} 1$ and represented in Fig. 3). In addition, the Langmuir $R_{L}$ values are between 0 and 1 for all metal ions in all systems and indicate that the biosorption of all the metal ions on RO and $\mathrm{LO}$ is favourable. The good agreement achieved with the Langmuir model suggests that there is probably an interaction between the metal species and homogeneous sorbent surfaces.

Furthermore, the maximum sorption capacity values for $\mathrm{Cr}(\mathrm{III}), \mathrm{Cu}(\mathrm{II})$ and $\mathrm{Pb}(\mathrm{II})$ in systems with a single heavy metal are properly collected in Table S1. As expected from our previous results, RO shows lower maximum sorption capacities than LO for all heavy metals in this study, which can be related to the different BET values of RO and LO (Table 4). Compared with RO, LO has higher BET values, which corresponds to a higher surface; thus, higher possible sorption sites and subsequently higher sorption rates are possible with LO, as evidenced here.

\section{Comparison of nonliving sterile and nonsterile biomass sorption capacity}

To investigate the contribution of microorganisms to the HM sorption process, nonliving biomass with and without microorganisms was used as a sorbent for HM removal.

The RO and LO bacterial cfu counts in the original nonliving biomass were $4.3 \cdot 10^{1}$ and $3.7 \cdot 10^{1} \mathrm{cfu} / \mathrm{mL}$, respectively. Thus, the original biomass naturally contains the associated microorganisms; consequently, rice and rapeseed biomass wastes were pretreated in an autoclave to eliminate live microorganisms to test the metal uptake of sterile biomass. In the same way, the role of biomass-associated microorganisms in the metal uptake process was quantified by using the original nonliving biomass. The sorption experiment results of both the original and sterile plant biomass wastes are plotted in Figs. 4 and 5 for rice (RO) and rapeseed (LO), respectively. Solutions containing multiple heavy metals in different amounts, from 0.05 to $4 \mathrm{mmol} / \mathrm{L}$, were evaluated.

Regarding RO, comparable findings were observed (Fig. 4). A higher specific HM removal ( $q$ ) with the original biomass is clear for all the tested concentrations of $\mathrm{Cr}(\mathrm{III})$, $\mathrm{Cu}(\mathrm{II})$ and $\mathrm{Cd}(\mathrm{II})$, highlighting the removal obtained at initial concentrations in solution of approximately $4 \mathrm{mmol} / \mathrm{L}$ for $\mathrm{Cr}(\mathrm{III})$ and $\mathrm{Cu}(\mathrm{II})$. However, no bacterial resistance to $\mathrm{Pb}(\mathrm{II})$ is observed here, indicating that the role of $\mathrm{RO}$ microorganisms is insignificant and that most HM sorption is achieved by rice biomass, which is most efficient at $4 \mathrm{mmol} / \mathrm{L}$.

The results concerning LO original biomass show higher sorption capacity removal values compared with microorganism-free samples (sterile biomass), especially when exposed to $\mathrm{Cr}$ (III), $\mathrm{Cu}$ (II) and $\mathrm{Pb}$ (II) (Fig. 5). This behaviour can be explained by the complementary role of the associated microorganisms in the HM capture process. However, at $4 \mathrm{mmol} / \mathrm{L} \mathrm{Pb}(\mathrm{II})$, a similar adsorption capacity $(q)$ was detected between both systems (original biomass and sterile biomass, with and without microorganisms, respectively). Most likely, because microorganisms cannot survive at such high concentrations of $\mathrm{Pb}$ (II) (Yuan et al. 2015), they cannot 
Fig. 5 Comparison of the sorption capacities of nonsterile and sterile rapeseed (LO) at different concentration levels of aqueous solutions with multiple HMs. Experimental conditions: $T=25 \pm 1{ }^{\circ} \mathrm{C}, \mathrm{pH} 4.0,25 \mathrm{mg}$ of sorbent, $2.5 \mathrm{~mL}$ of metal solution and a contact time of $24 \mathrm{~h}$
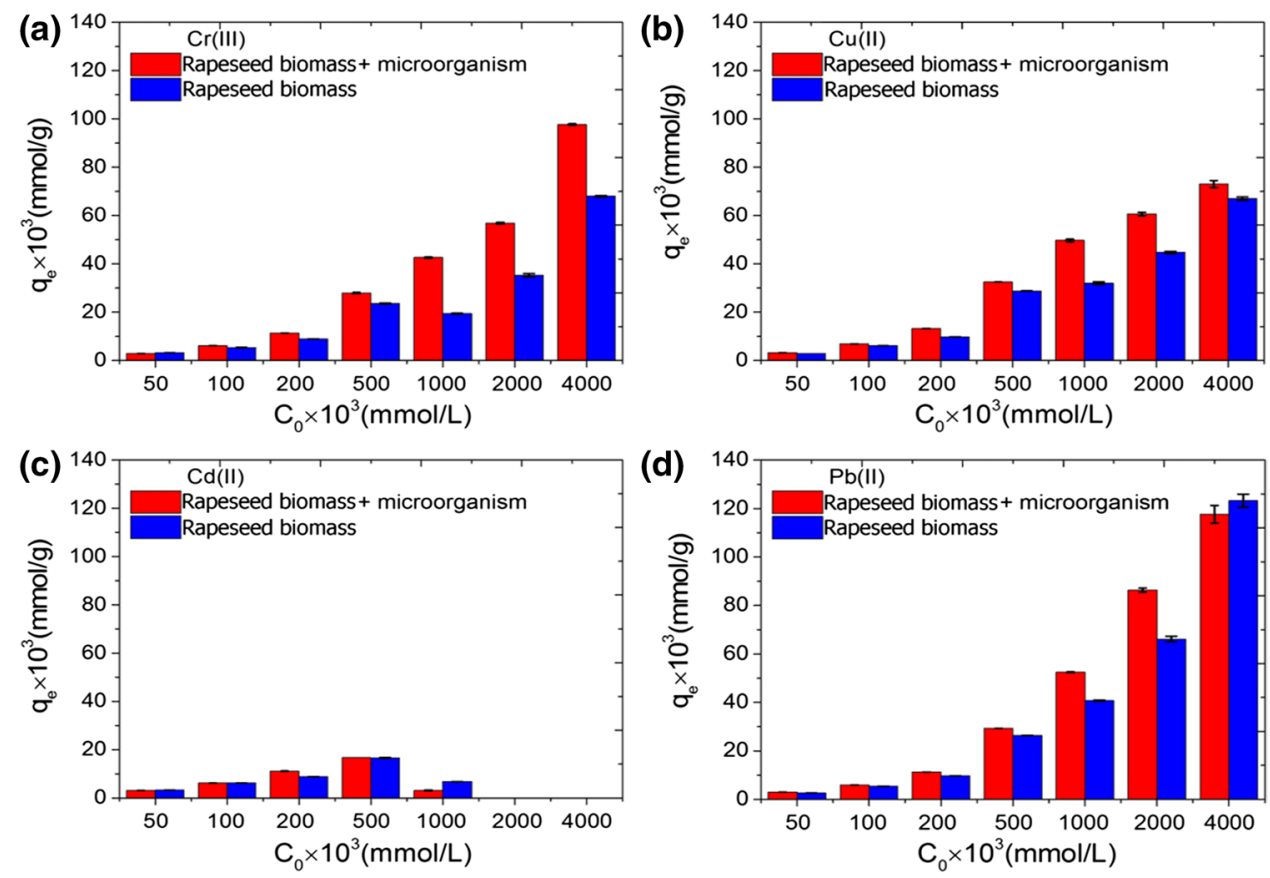

have any role in the rice and rapeseed sorption capacity. Interestingly, microorganisms show a lower capacity for Cd(II) removal than for the other metals under checked, presumably due to a low tolerance to this metal (Fig. 5c), as reported previously (Villagrasa et al. 2021).

These experiments demonstrated the likely role of biomass-associated microorganisms in enhancing heavy metal removal (Ayangbenro and Babalola 2017), especially in the case of rapeseed original nonliving biomass systems. Thus, to determine whether microorganisms exhibit resistance to HMs and their corresponding adsorption capacity to remove HMs (at the same concentration range), the isolated microorganisms were examined as sorbents in aqueous solutions with multiple HMs.

\section{Removal capabilities of the isolated microorganisms}

Metal exposure experiments with cell cultures were developed to address the following: whether the strains can indeed contribute to HM removal and the amount of HM captured by them. These experiments were tested in a rich culture medium (LB) to determine the role of microorganisms without being under nutrient starvation conditions.

The results referred to this section are provided in Table 5. First, pure isolated microorganism cultures were evaluated. Once they reached the exponential phase of growth, they were subjected to $\mathrm{Cr}(\mathrm{III}), \mathrm{Cd}(\mathrm{II}), \mathrm{Cu}(\mathrm{II})$ and $\mathrm{Pb}(\mathrm{II})$, each culture in separate aqueous solutions, at a final concentration of $0.18 \mathrm{mmol} / \mathrm{L}$ of each metal (in a multiple HM system). These experiments resulted in the active participation of all the isolated strains in the $\mathrm{Pb}$ (II) capture process, with
Table 5 Sorption of HMs by microorganisms (mg/L). The initial HM solution was $0.18 \mathrm{mmol} / \mathrm{L}$ for each element (Cr(III) $9.35, \mathrm{Cu}$ (II) 11.4, $\mathrm{Cd}$ (II) 20.3 and $\mathrm{Pb}$ (II) $38.0 \mathrm{mg} / \mathrm{L}$ )

\begin{tabular}{lllll}
\hline Strain & $\mathrm{Cr}(\mathrm{III})$ & $\mathrm{Cu}(\mathrm{II})$ & $\mathrm{Cd}(\mathrm{II})$ & $\mathrm{Pb}(\mathrm{II})$ \\
\hline $\begin{array}{l}\text { CON- } \\
\text { TROL* }\end{array}$ & 0 & 0 & 0 & 0 \\
$\mathrm{R} 01$ & 0 & $0.180 \pm 0.020$ & 0 & \\
$\mathrm{R} 02$ & 0 & 0 & $0.700 \pm 0.040$ & $13.7 \pm 0.1$ \\
$\mathrm{R} 03$ & 0 & 0 & 0 & $5.24 \pm 0.08$ \\
R04 & 0 & 0 & $1.02 \pm 0.04$ & $14.8 \pm 0.1$ \\
L01-L02 & 0 & 0 & $0.620 \pm 0.060$ & $11.8 \pm 0.1$ \\
L03 & 0 & 0 & 0 & $4.64 \pm 0.08$ \\
L04 & 0 & 0 & 0 & $7.66 \pm 0.08$ \\
Mix rice & $8.66 \pm 0.02$ & $11.9 \pm 0.1$ & $18.4 \pm 0.1$ & $36.8 \pm 0.1$ \\
$\quad$ strains & & & & \\
Mix canola & $8.66 \pm 0.02$ & $11.9 \pm 0.1$ & $18.6 \pm 0.2$ & $37.1 \pm 0.1$ \\
strains & & & & \\
\hline
\end{tabular}

relatively high efficiencies, the most notable being $38.00 \%$ (strain R04), 35.30\% (strain R02) and 30.44\% (strains L01L02). The values collected for R01, R03, L03 and L04 are $25.02 \%, 13.50 \%, 11.95 \%$ and $19.72 \%$, respectively. Nonetheless, the involvement of the strains exposed to $\mathrm{Cr}(\mathrm{III}), \mathrm{Cd}(\mathrm{II})$ or $\mathrm{Cu}(\mathrm{II})$ can be dismissed. Although positive specific HM removal capacity $(q)$ values are recovered for $\mathrm{R} 01-\mathrm{Cu}(\mathrm{II})$; L01-Cd(II); L02-Cd(II); R02-Cd(II); and R04-Cd(II), they are too low to consider the strains as active participants in the HM uptake process. These findings may be largely related to the metal toxicity susceptibility of these strains when they are single cultured (Nguyen et al. 2015; Aparicio 
et al. 2018). It has been widely reported that certain concentrations of HM ions can affect the morphology, growth and metabolism of microorganisms by drastically altering their cell membranes, changing their nucleic acid structure, restricting enzyme activity, etc., which consequently reduces cell viability (Fashola et al. 2016; Igiri et al. 2018).

As RO and LO biomass microbiomes are composed of mixed populations, mixed cultures must also be explored. The importance of testing consortia cultures remains in the cooperative actions they perform in an ecosystem that are not contemplated in pure cultures. As previously described, consortia culture cells were grown to exponential phase and then added to a $0.18 \mathrm{mmol} / \mathrm{L} \mathrm{HM}$ multiple solution system. The results acquired here are remarkable, with some removal capacity found in that case for $\mathrm{Cr}(\mathrm{III}), \mathrm{Cd}(\mathrm{II})$ and $\mathrm{Cu}(\mathrm{II})$, compared with previous results in single cultures. Particularly for $\mathrm{Pb}(\mathrm{II})$, as noted from the pure culture experiments (Table 5), both biomasses demonstrate the participation of these consortia in the HM uptake process. The contribution percentage is over $80 \%$ of the total HM. Interestingly, similar ranges of metal removal and uptake efficiency $(\mathrm{Pb}(\mathrm{II})>\mathrm{Cd}($ II $)>\mathrm{Cu}(\mathrm{II})>\mathrm{Cr}(\mathrm{III})$ ) were found with the consortia of both rice and rapeseed wastes.

\section{Role of nonliving biomass-associated microorganisms in the HM biosorption process}

From the above-mentioned results, it can be confirmed that after $24 \mathrm{~h}$ of exposure, the microorganisms associated with both biomasses play a role in the HM biosorption process. In addition, with longer exposure times, these microorganisms (with some resistance to HM) would develop exponentially, and therefore, they would participate in promoting the HM biosorption process. Several studies have previously reported the use of a microbial consortium for remediation, which is considered more effective than single strain pure culture (Dipak and Sankar 2015; Gupta and Kumar 2017). As expected, microorganisms are more resistant to HMs in mixed cultures, probably due to the physiological diversity between each strain and the different tolerance mechanisms towards HMs. Therefore, this resistance will develop a properly adapted and strong consortium through the exchange of genetic material between the present strains. Therefore, most strains can tolerate and remove these heavy metals and thus assist rapeseed and rice biomass in HM elimination.

Further studies are required to determine the mechanisms of the present strains on the HM removal capability and efficiency and to understand the metabolic pathways and genes responsible for these processes (Mosa et al. 2016). However, it can be initially predicted that the obtained results will be diverse since the genus Bacillus has been largely described to adopt both metal biosorption and bioaccumulation mechanisms (Çolak et al. 2011; Huang et al. 2018; Wu et al. 2017; Jin et al. 2018). Moreover, it is well known that gram-positive microorganisms have excellent biosorption capability due to their thick layer of peptidoglycan, which includes an abundant number of sorption sites (Song and Tao 2013; Yin et al. 2019).

\section{Conclusion}

In this work, rice (RO) and rapeseed (LO) residues are successfully used as nonliving biomass sorbents for the removal of $\mathrm{Cr}(\mathrm{III}), \mathrm{Cu}$ (II), $\mathrm{Cd}$ (II) and $\mathrm{Pb}$ (II) from multimetal aqueous systems, and the sorption processes are investigated and discussed in this paper. Furthermore, it is important to highlight that this is the first time that the presence of microorganisms in these nonliving biomasses has been taken into account and properly described, being different in each RO and LO case. Regarding the RO biomass, gram-positive bacteria are exclusively from the genus Bacillus, while the LO contains both gram-positive bacteria that belongs to the genera Micrococcus and Staphylococcus and gram-negative bacteria (genus Escherichia). The results show that both nonliving biomass residues can be used to remove heavy metals from wastewater systems, and the participation of isolated microorganisms in consortia during the metal sorption process has been confirmed here.

In this sense, it can be concluded that there is no need for any special pretreatment against the microorganisms in the nonliving biomass waste samples of $\mathrm{RO}$ and $\mathrm{LO}$ prior to their use as metal sorbents, which implies their good feasibility for application from an economic point of view.

Supplementary Information The online version contains supplementary material available at https://doi.org/10.1007/s13762-022-04000-6.

Acknowledgements All the authors are grateful to L. López who helped on the performance of some experiments and the analysis of heavy metals by ICP-MS.

Authors' contributions X.J. Shen, J. Zhao and N. Bonet-Garcia contributed to conceptualization, methodology, formal analysis, investigation, data curation and writing - original draft preparation. E. Villagrasa was involved in conceptualization, methodology and writing-reviewing and editing. A. Solé contributed to conceptualization, methodology and reviewing. X. Liao and C. Palet were involved in conceptualization, methodology, writing - reviewing, editing, supervision and funding acquisition. All authors reviewed and approved the final manuscript for publication.

Funding Open Access Funding provided by Universitat Autonoma de Barcelona. This research was supported by grants from the National Key Research and Development Program of China (No. 2018YFD0200904) and the Agricultural Science and Technology Innovation Program of China (No. CAAS-ASTIP-2013-OCRI), by the Spanish research projects (Nos. CTM2015-65414-C2-1-R and AGL2015-70393-R) and by the China Scholarship Council (for J. Zhao-No. 201509110114). 
Data availability All data generated or analysed during this study are included in this manuscript.

\section{Declarations}

Conflict of interset The authors declare no competing interests.

Consent to publish The authors declare their consent for the publication of this manuscript.

Ethical approval Not applicable.

Consent to participate Not applicable.

Open Access This article is licensed under a Creative Commons Attribution 4.0 International License, which permits use, sharing, adaptation, distribution and reproduction in any medium or format, as long as you give appropriate credit to the original author(s) and the source, provide a link to the Creative Commons licence, and indicate if changes were made. The images or other third party material in this article are included in the article's Creative Commons licence, unless indicated otherwise in a credit line to the material. If material is not included in the article's Creative Commons licence and your intended use is not permitted by statutory regulation or exceeds the permitted use, you will need to obtain permission directly from the copyright holder. To view a copy of this licence, visit http://creativecommons.org/licenses/by/4.0/.

\section{References}

Abdel-Ghani N, El-Chaghaby G (2014) Biosorption for metal ions removal from aqueous solutions: a review of recent studies. Int $\mathrm{J}$ Latest Res Sci Technol 3(1):24-42

Alori ET, Glick BR, Babalola OO (2017) Microbial phosphorus solubilization and its potential for use in sustainable agriculture. Front Microbiol 8:971. https://doi.org/10.3389/fmicb.2017.00971

Anthony JE (1931) Scientific apparatus and laboratory methods: a note on capsule staining. Science 73(1890):319-320. https://doi.org/ 10.1126/science.73.1890.319

Aparicio JD, Saez JM, Raimondo EE, Benimeli CS, Polti MA (2018) Comparative study of single and mixed cultures of actinobacteria for the bioremediation of co-contaminated matrices. J Environ Chem Eng 6:2310-2318. https://doi.org/10.1016/j.jece.2018.03. 030

Ayangbenro AS, Babalola OO (2017) A new strategy for heavy metal polluted environments: a review of microbial biosorbents. Int $\mathbf{J}$ Environ Res Public Health 14:94. https://doi.org/10.3390/ijerp h14010094

Azizullah A, Khattak MNK, Richter P, Häder DP (2011) Water pollution in Pakistan and its impact on public health: a review. Environ Int 37(2):479-497. https://doi.org/10.1016/j.envint.2010.10.007

Bergey DH, Holt JG (1994) Bergey's manual of determinative bacteriology, 9th edn. Williams \& Wilkins, Baltimore (Maryland)

Bhattacharya A, Dey P, Gola D, Mishra A, Malik A, Patel N (2015) Assessment of Yamuna and associated drains used for irrigation in rural and peri-urban settings of Delhi NCR. Environ Monit Assess 187:4146. https://doi.org/10.1007/s10661-014-4146-2

Calderón OAR, Abdeldayem OM, Pugazhendhi A, Rene ER (2020) Current updates and perspectives of biosorption technology: an alternative for the removal of heavy metals from wastewater. Curr Pollut Rep 6:8-27. https://doi.org/10.1007/s40726-020-00135-7

Cárdenas-Aguiar E, Suárez G, Paz-Ferreiro J, Askeland MPJ, Méndez A, Gascó G (2020) Remediation of mining soils by combining
Brassica napus growth and amendment with chars from manure waste. Chemosphere 261:127798. https://doi.org/10.1016/j.chemo sphere. 2020.127798

Carolin CF, Kumar PS, Saravanan A, Joshiba GJ, Naushad M (2017) Efficient techniques for the removal of toxic heavy metals from aquatic environment: a review. J Environ Chem Eng 5(3):27822799. https://doi.org/10.1016/j.jece.2017.05.029

Cole JR, Wang Q, Fish JA, Chai B, McGarrell DM, Sun Y, Brown CT, Porras-Alfaro A, Kuske CR, Tiedje JM (2014) Ribosomal database project: data and tools for high throughput rRNA analysis. Nucleic Acids Res 42(D1):633-642. https://doi.org/10.1093/nar/ gkt1244

Çolak F, Atar N, Yazicioğlu D, Olgun A (2011) Biosorption of lead from aqueous solutions by Bacillus strains possessing heavy-metal resistance. Chem Eng J 73(2):442-428. https://doi.org/10.1016/j. cej.2011.07.084

Dai L, Wang L, Li L, Liang T, Zhang Y, Ma C, Xing B (2018) Multivariate geostatistical analysis and source identification of heavy metals in the sediment of Poyang Lake in China. Sci Tot Environ 621:1433-1444. https://doi.org/10.1016/j.scitotenv.2017.10.085

Dipak P, Sankar NS (2015) Biological removal of phosphate using phosphate solubilizing bacterial consortium from synthetic wastewater: a laboratory scale. Environ Asia 8:1-8. https://doi.org/10. 14456/ea.2015.1

Doetsch RN (1981) Determinative methods of light microscopy. In: Gerhardt P, Murray RGE, Costilow RN, Nester EW, Wood WA, Krieg NR, Phillips GB (eds) Manual of methods for general bacteriology. American Society for Microbiology, Washington, pp 21-33

El-Hassanin AS, Samak MR, Radwan SR, El-Chaghaby GA (2020) Preparation and characterization of biochar from rice straw and its application in soil remediation. Environ Nat Resour J 18(3):283289. https://doi.org/10.32526/ennrj.18.3.2020.27

Fashola M, Ngole-Jeme V, Babalola O (2016) Heavy metal pollution from gold mines: environmental effects and bacterial strategies for resistance. Int J Environ Res 13:1047. https://doi.org/10.3390/ ijerph13111047

Feizi M, Jalali M (2015) Removal of heavy metals from aqueous solutions using sunflower, potato, canola and walnut shell residues. J Taiwan Inst Chem Eng 54:125-136. https://doi.org/10.1016/j. jtice.2015.03.027

Food and Agriculture Organization of the United Nations (FAO) (2014) Global information and early warning system on food and agriculture (GIEWS), Food Outlook. Rome, Italy. 2014; pp 186. http:// www.fao.org/giews/english/fo/index.htm.

Ghaffar SH, Fan M (2014) Lignin in straw and its applications as an adhesive. Int J Adhes Adhes 48:92-101. https://doi.org/10.1016/j. ijadhadh.2013.09.001

Ghavami N, Alikhani HA, Pourbabaei AA, Besharati H (2017) Effects of two new siderophore-producing rhizobacteria on growth and iron content of maize and canola plants. J Plant Nutr 40(5):736746. https://doi.org/10.1080/01904167.2016.1262409

Gupta P, Kumar V (2017) Value added phytoremediation of metal stressed soils using phosphate solubilizing microbial consortium. World J Microbiol Biotechnol 33:9. https://doi.org/10.1007/ s11274-016-2176-3

Hashem A, Tabassum B, Abd_Allah EF (2019) Bacillus subtilis: a plant-growth promoting rhizobacterium that also impacts biotic stress. Saudi J Biol Sci 26(6):1291-1297. doi:https://doi.org/10. 1016/j.sjbs.2019.05.004

Høvik HG, Sørheim R (1991) Improved method for phenotypical characterization of marine bacteria. J Microbiol Methods 13:231-241. https://doi.org/10.1016/0167-7012(91)90049-V

Huang F, Gao LY, Deng JH, Chen SH, Cai KZ (2018) Quantitative contribution of $\mathrm{Cd}^{2+}$ adsorption mechanisms by 
chicken-manure-derived biochars. Environ Sci Pollut Res 25(28):28322-28334. https://doi.org/10.1007/s11356-018-2889-y

Igiri BE, Okoduwa S, Idoko GO, Akabuogu EP, Adeyi AO, Ejiogu IK (2018) Toxicity and bioremediation of heavy metals contaminated ecosystem from tannery wastewater: a review. J Toxic. https://doi. org/10.1155/2018/2568038

Jain N, Johnson TA, Kumar A, Mishra S, Gupta N (2015) Biosorption of Cd (II) on jatropha fruit coat and seed coat. Environ Monit Assess 187(7):1-12. https://doi.org/10.1007/s10661-015-4658-4

Jin Y, Luan Y, Ning Y, Wang L (2018) Effects and mechanisms of microbial remediation of heavy metals in soil: a critical review. Appl Sci 8:1336. https://doi.org/10.3390/app8081336

Kim JR, Kan E (2016) Heterogeneous photocatalytic degradation of sulfamethoxazole in water using a biochar-supported $\mathrm{TiO}_{2}$ photocatalyst. J Environ Manage 180:94-101. https://doi.org/10.1016/j. jenvman.2016.05.016

Kumar D, Khan EA (2021) Remediation and detection techniques for heavy metals in the environment. Heavy Met Environ. Elsevier. pp 205-222. https://doi.org/10.1016/B978-0-12-821656-9.00012-2

Luo S, Cai T, Liu C, Zhang Y, Liu Y, Ma J, Wei Y, Ali O, Zhang S (2017) Fast adsorption of heavy metal ions by waste cotton fabrics based double network hydrogel and influencing factors insight. J Hazard Mater 344:1034-1042. https://doi.org/10.1016/j.jhazm at.2017.11.041

Luyt CD, Tandlich R, Muller WJ, Wilhelmi BS (2012) Microbial monitoring of surface water in south Africa: an overview. Int J Environ Res Public Health 9(8):2669-2693. https://doi.org/10.3390/ijerp h9082669

Maldonado J, Diestra E, Domènech AM, Villagrasa E, Puyen ZM, Esteve I, Solé A (2010) Isolation and identification of a bacterium with high tolerance to lead and copper from a marine microbial mat in Spain. Ann Microbiol 60(1):113-120. https://doi.org/10. 1007/s13213-010-0019-2

Hubbe MA (2021) Insisting upon meaningful results from adsorption experiments. Sep Purif Rev. https://doi.org/10.1080/15422119. 2021.1888299

Martín JR, De Arana C, Ramos-Miras JJ, Gil C, Boluda R (2015) Impact of 70 years urban growth associated with heavy metal pollution. Environ Pollut 196:156-163. https://doi.org/10.1016/j. envpol.2014.10.014

Mebane CA, Schmidt TS, Miller JL, Balistrieri LS (2020) Bioaccumulation and toxicity of cadmium, copper, nickel, and zinc and their mixtures to aquatic insect communities. Environ Toxicol Chem 39(4):812-833. https://doi.org/10.1002/etc.4560

Mosa KA, Saadoun I, Kumar K, Helmy M, Dhankher OP (2016) Potential biotechnological strategies for the cleanup of heavy metals and metalloids. Front Plant Sci 7:303. https://doi.org/10.3389/ fpls.2016.00303

Nath D, Maurya BR, Meena VS (2017) Documentation of five potassium-and phosphorus-solubilizing bacteria for their $\mathrm{K}$ and P-solubilization ability from various minerals. Biocatal Agric Biotechnol 10:174-181. https://doi.org/10.1016/j.bcab.2017.03.007

Nguyen TAH, Ngo HH, Guo WS, Zhang J, Liang S, Yue QY, Li Q, Nguyen TV (2013) Applicability of agricultural waste and byproducts for adsorptive removal of heavy metals from wastewater. BioresTechnol 148:574-585. https://doi.org/10.1016/j.biortech. 2013.08.124

Nguyen VK, Lee MH, Park HJ, Lee JU (2015) Bioleaching of arsenic and heavy metals from mine tailings by pure and mixed cultures of Acidithiobacillus spp. J Ind Eng Chem 21:451-458. https://doi. org/10.1016/j.jiec.2014.03.004

Plank J, Christian H (2007) Impact of zeta potential of early cement hydration phases on superplasticizer adsorption. Cem Concr Res 37(4):537-542doi:https://doi.org/10.1016/j.cemconres.2007.01. 007
Sayah RS, Kaneene JB, Johnson Y, Miller RA (2005) Patterns of antimicrobial resistance observed in Escherichia coli isolates obtained from domestic- and wild-animal fecal samples, human septage, and surface water. Appl Environ Microbiol 71(3):1394-1404. https://doi.org/10.1128/AEM.71.3.1394-1404.2005

Schaeffer AB, Fulton MD (1933) A simplified method of staining endospores. Science 77(1990):194. https://doi.org/10.1126/scien ce.77.1990.194

Sčíban M, Radetic B, Kevrešan Z, Klašnja M (2007) Adsorption of heavy metals from electroplating wastewater by wood sawdust. Bioresour Technol 98(2):402-409. doi:https://doi.org/10.1016/j. biortech.2005.12.014

Senthil Kumar P, Gunasundari E (2018) Bioremediation of heavy metals. In: Varjani S, Agarwal A, Gnansounou E, Gurunathan B (eds) Bioremediation: applications for environmental protection and management. Energy Environ Sustain. Springer, Singapore. doi:https://doi.org/10.1007/978-981-10-7485-1_9

Sharma RK, Wooten JB, Baliga VL, Lin XH, Chan WG, Hajaligol MR (2004) Characterization of chars from pyrolysis of lignin. Fuel 83(11-12):1469-1482. https://doi.org/10.1016/j.fuel.2003.11.015

Shen Z, Zhang Y, Jin F, McMillan O, Al-Tabbaa A (2017) Qualitative and quantitative characterisation of adsorption mechanisms of lead on four biochars. Sci Tot Environ 609:1401-1410. https:// doi.org/10.1016/j.scitotenv.2017.08.008

Song P, Tao HC (2013) Cell surface engineering of microorganisms towards adsorption of heavy metals. Crit Rev Microbiol 41:140 149. https://doi.org/10.3109/1040841X.2013.813898

Tchounwou PB, Yedjou CG, Patlolla AK, Sutton DJ (2012) Heavy metal toxicity and the environment. Exp Suppl 101:133-164. https://doi.org/10.1007/978-3-7643-8340-4_6

Vijver MG, Elliott EG, Peijnenburg WJ, De Snoo GR (2011) Response predictions for organisms water-exposed to metal mixtures: a meta-analysis. Environ Toxicol Chem 30(6):1482-1487. https:// doi.org/10.1002/etc.499

Villagrasa E, Palet C, López-Gómez I, Gutiérrez D, Esteve I, SánchezChardi A, Solé A (2021) Cellular strategies against metals exposure and metal localization patterns linked to phosphorus pathways in Ochrobactrum anthropi DE2010. J Hazard Mater. https:// doi.org/10.1016/j.jhazmat.2020.123808

Wang ZY, Liu GC, Zheng H, Li FM, Ngo HH, Guo WS, Liu C, Chen L, Xing BS (2015) Investigating the mechanisms of biochar's removal of lead from solution. Bioresour Technol 177:308-317. https://doi.org/10.1016/j.biortech.2014.11.077

Wood AP. and Kelly DP (2010) Skin microbiology, body odor, and methylotrophic bacteria. In: Timmis KN (ed), Handbook of hydrocarbon and lipid microbiology. Doi:https://doi.org/10.1007/9783-540-77587-4_243

Wu M, Liang J, Tang J, Li G, Shan S, Guo Z, Deng L (2017) Decontamination of multiple heavy metals-containing effluents through microbial biotechnology. J Hazard Mater 337:189-197. https:// doi.org/10.1016/j.jhazmat.2017.05.006

Yin K, Wang QN, Chen LX (2019) Microorganisms remediation strategies towards heavy metals. Chem Eng J 360:1553-1563. https:// doi.org/10.1016/j.cej.2018.10.226

Yu P, Wang X, Zhang K et al (2020) Continuous purification of simulated wastewater based on rice straw composites for oil/water separation and removal of heavy metal ions. Cellulose 27:5223-5239. https://doi.org/10.1007/s10570-020-03135-4

Yuan L, Zhi W, Liu Y, Karyala S, Vikesland PJ, Chen X, Zhang H (2015) Lead toxicity to the performance, viability, and community composition of activated sludge microorganisms. Environ Sci Technol 49(2):824-830. https://doi.org/10.1021/es504207c

Zhan C, Sharma PR, He H, Sharma SK, McCauley-Pearl A, Wang R, Hsiao BS (2020) Rice husk based nanocellulose scaffolds for highly efficient removal of heavy metal ions from contaminated 
water. Environ Sci: Water Res Technol 6(11):3080-3090. https:// doi.org/10.1039/D0EW00545B

Zhang H, Carrillo-Navarrete F, Palet C (2020) Human hair biogenic fiber as a biosorbent of multiple heavy metals from aqueous solutions. J Natural Fibers. https://doi.org/10.1080/15440478.2020. 1798841

Zhao JJ, Shen XJ, Domene X, Alcañiz JM, Liao X, Palet C (2019) Comparison of biochars derived from different types of feedstock and their potential for heavy metal removal in multiplemetal solutions. Sci Rep 9:9869. https://doi.org/10.1038/ s41598-019-46234-4

Zhao JJ, Boada R, Cibin G, Palet C (2020a) Enhancement of selective adsorption of $\mathrm{Cr}$ species via modification of pine biomass. Sci Total Environ 20(756):143816. https://doi.org/10.1016/j.scitotenv. 2020.143816
Zhao L, Gong D, Zhao W, Lin 1, Yang W, Guo W, Tang X, Qingyun Li (2020b) Spatial-temporal distribution characteristics and health risk assessment of heavy metals in surface water of the Three Gorges Reservoir, China. Sci Total Environ 704:134883. doi:https://doi.org/10.1016/j.scitotenv.2019.134883

Zhao Z, Zhou WJ (2019) Insight into interaction between biochar and soil minerals in changing biochar properties and adsorption capacities for Sulfamethoxazole. Environ Pollut 245:208-217. https:// doi.org/10.1016/j.envpol.2018.11.013

Zhou H, Zhou X, Zeng M, Liao BH, Liu L, Yang WT, Wu YM, Qin YQ, Wang YJ (2014) Effects of combined amendments on heavy metal accumulation in rice (Oryza sativa L.) planted on contaminated paddy soil. Ecotoxicol Environ Saf 101:226-232. https:// doi.org/10.1016/j.ecoenv.2014.01.001 